\title{
LITERARY THICKNESS
}

\section{Rafe McGregor}

In this paper, I shall demonstrate the value of the concept of literary thickness - i.e. formcontent inseparability - as a tool of literary appreciation. I set out the relationships between non-fiction, fiction, literature, and poetry in section 1 and sketch a preliminary definition of literary thickness in section 2 . I argue that a convincing account of reference in literary fictions can be provided by means of literary thickness in sections 3 and 4 . I argue that the match between authorial intention and reader response characteristic of the experience of literary works is explained by literary thickness in section 5 . In section 6 , I test the usefulness of the concept of literary thickness against Peter Carey's True History of the Kelly Gang.

\section{Fiction \& Literature}

For the purposes of this paper, I shall adopt the standard philosophical account of the distinction between fiction and non-fiction - despite the pressure to which it has recently been subjected. ${ }^{1}$ Peter Lamarque and Stein Haugom Olsen offer a much-cited version of this account as follows:

\footnotetext{
${ }^{1}$ In particular, see: Stacie Friend, "Fiction as a Genre," Proceedings of the Aristotelian Society CXII (2012), 179-209 and Derek Matravers, Fiction and Narrative (Oxford: Oxford University Press, 2014).
} 
the fictive dimension of stories (or narratives) is explicable only in terms of a rulegoverned practice, central to which are a certain mode of utterance (fictive utterance) and a certain complex of attitudes (the fictive stance). ${ }^{2}$

To create a work of fiction in an oral or written tradition is to make a fictive utterance and to experience that work as a work of fiction is to adopt the fictive stance. As Stacie Friend notes, the standard account is reliant upon the distinctive roles of imagination and belief in the two categories: a fictive utterance invites readers to imagine its contents while a factive utterance invites readers to believe its contents. ${ }^{3}$ Just as Lamarque and Olsen conceive of a fictive work as a fictive utterance, so a literary work is identified on the basis of the intention of the author, specifically 'the intention to invoke a literary response.' ${ }^{4}$ Similarly, to read a text as literature is to adopt the literary stance:

Adopting the literary stance towards a text is to identify it as a literary work and apprehend it in accordance with the conventions of the literary practice. The mode of apprehension which the practice defines is one of appreciation. ${ }^{5}$

To appreciate a work is to recognise its value; specifically, to grasp the literary value of a literary work. The concepts of fiction and literature are clearly not coextensive, however, as there are works of fiction that are not works of literature and works of literature that are not works of fiction.

In the former case, this may be because the work belongs to another art form, for example a cinematic work, such as Christopher Nolan's Memento; or because the work does not aspire to a distinctively literary kind of attention, for example Agatha Christie's And Then There Were None. The category of literary works that are not fictional includes historical,

\footnotetext{
${ }^{2}$ Peter Lamarque \& Stein Haugom Olsen, Truth, Fiction, and Literature: A Philosophical Perspective (Oxford: Clarendon, 2002), 32.

${ }^{3}$ Friend, "Fiction as a Genre," 182.

${ }^{4}$ Lamarque \& Olsen, Truth, Fiction, and Literature, 256.

${ }^{5}$ Lamarque \& Olsen, Truth, Fiction, and Literature, 256.
} 
documentary, and philosophical works - such as William H. Prescott's History of the Conquest of Peru, George Orwell's Homage to Catalonia, and Friedrich Nietzsche's Thus Spoke Zarathustra, A Book for All and None - which are judged to have literary value. ${ }^{6}$ I shall take "fiction" as a descriptive concept and "literature" as an evaluative one: Ulysses and And Then There Were None are both fictional works, but only Ulysses is (also) a literary work, i.e. both invites and rewards literary attention. Despite the significance of the differences between fiction and literature, and the historical problems in the relationship to which Lamarque and Olsen allude, they hold that 'literature for the most part consists of stories that are either invented by the author or are mythical or legendary in character'. ${ }^{7}$ I shall take the literary stance as characteristically incorporating the fictive stance, accepting Olsen's claim that 'the assumption that literature is invention and imagination, "story" and not "history", is central to literary practice', employing "literature" to refer to this inventive, imaginative sub-category of works. "Literary work" should therefore be understood as synonymous with "literary fiction" hereafter.

Literature as delineated above is an art form and to adopt the literary stance to a text is to experience the text as a work of art. I do not wish to commit to a definition of art, but the characterisations of fiction and literature I have accepted - particularly the references to "practices" and "conventions" - are compatible with the institutional theory of art. George Dickie is the leading proponent of this theory and his version is based on a series of five interlocking definitions - artist, work, public, artworld, and artworld system - with a work of art defined as 'an artifact of a kind created to be presented to an artworld public.' 9 Dickie is unconcerned by the circularity of the definition because its function is not identification, but

\footnotetext{
${ }^{6}$ Some lyric poetry is also categorised as literary non-fiction.

${ }^{7}$ Lamarque \& Olsen, Truth, Fiction, and Literature, 268.

${ }^{8}$ Stein Haugom Olsen, The End of Literary Theory (New York: Cambridge University Press, 1987), 160.

${ }^{9}$ George Dickie, The Art Circle (New York: Haven, 1984), 80.
} 
the clarification and explanation of an already familiar term: 'Virtually everyone can recognize some things as works of art' ${ }^{10}$ I shall take this to be true of some works of literary art and focus on two works whose status as literature is uncontested. The literary stance and the author's intention to invoke this stance are reliant upon the practice of literature, the set of concepts and conventions that constitute the institutional framework within which literary works are presented and received.

\section{Form \& Content}

Plato $^{11}$ distinguished the 'style' of stories from their 'content' and while there has been philosophical interest in the relationship between form and content ever since, A.C. Bradley's "Poetry for Poetry's Sake" lecture marks the beginning of the contemporary concern. ${ }^{12}$ In a previous paper, I developed Bradley's largely unsubstantiated argument for form-content inseparability in the light of subsequent work by I.A. Richards ${ }^{13}$ and Lamarque, ${ }^{14}$ proposing a reciprocal relationship between form and content he calls poetic thickness. ${ }^{15}$ Recently, I have further argued that there is a similarly close relationship between form and content in literary narratives, called narrative thickness. ${ }^{16}$ I want to subsume both of these instantiations under a single concept that is applicable to all works of literary art, both poetic and narrative. With this aim in mind, it is interesting to consider Anna Christina Ribeiro's explanation of the characteristics that typically (rather than necessarily) set poetic works apart from other works of literature:

\footnotetext{
${ }^{10}$ Dickie, The Art Circle, 79.

${ }^{11}$ Plato, Republic, trans. G.M.A. Grube \& C.D.C. Reeve, in J.M. Cooper, ed., Plato: Complete Works (Indianapolis: Hackett, 1997), 971-1223, III: 392c5-7.

12 A.C. Bradley, "Poetry for Poetry's Sake," in A.C. Bradley, Oxford Lectures on Poetry (London: Macmillan, 1959), 3-34.

${ }^{13}$ I.A. Richards, Principles of Literary Criticism (London: Kegan, Paul, Trench, Trübner \& Co, 1930) and

Practical Criticism: A Study of Literary Judgment (London: Routledge, 1978).

${ }^{14}$ Peter Lamarque, “The Elusiveness of Poetic Meaning," Ratio 22 (2009), 398-420.

15 Rafe McGregor, "Poetic Thickness," British Journal of Aesthetics 54 (2014), 49-64.

${ }^{16}$ Rafe McGregor, "Narrative Thickness," Estetika LII (2015), 3-22.
} 
(1) most poems are lyric poems written in the first person; (2) most poems are formal; indeed, most are highly formal; and (3) most poems use figurative language metaphors, similes, imagery, and so on, to a greater, often much greater, extent than other literary forms. ${ }^{17}$

All three of these characteristics (four, if one counts the first person voice) - musical quality, formal salience, and tropes are also associated with literary narratives, albeit (as Ribeiro notes) standardly to a lesser extent. The three are also all formal rather than substantive features and my claim is that all three categories of literary art - poems, plays, and novels (including shorter novellas and even shorter short stories) - share a common set of formal and substantive features. Literary form includes structure, morphology (the patterns of word formation), syntax (the rules of sentence formation), metre (the arrangement of words in regularly measured, patterned, or rhythmic lines or verses), and tropes (all literary or rhetorical devices that use words in other than their literal sense). Content includes subject, theme, characters, settings, and events. Following Plato, Bradley offers a simple and effective description of the distinction: form is how a poet says something; content is what the poet says. ${ }^{18}$ My poetic thickness and narrative thickness can thus be subsumed under a preliminary definition of literary thickness as follows:

LITERARY THICKNESS I: the inseparability of literary form and literary content in the experience of a literary work such that neither form nor content can be isolated. Literary thickness is a demand which is satisfied by a work and is characteristic of literature such that if a work is a work of literature, it will reward the demand for literary thickness.

\footnotetext{
${ }^{17}$ Anna Christina Ribeiro, “Towards a Philosophy of Poetry,” Midwest Studies in Philosophy XXXIII (2009), 61-77: 66.

${ }^{18}$ Bradley, "Poetry for Poetry’s Sake,” 7-8. See also Plato, Republic III: 394c8-10.
} 
Literary thickness is consistent with my previous claim that not all works will reward the demand. ${ }^{19}$ The demand should therefore be understood as twofold, from both the reader and the work, as suggested by Malcolm Budd: 'the experience a work offers is an experience of interacting with it in whatever way it demands if it is to be understood. ${ }^{20}$ The demand made by the work is determined by the intention and ability of the author such that not all works that are intended to be appreciated - intended to meet the demand for literary thickness - will succeed in this aim. A work that fails in this way is a work which merely aspires to be literary.

The first part of my argument for the value of literary thickness as a tool of literary appreciation concerns fictional reference in literary works. Lamarque and Olsen distinguish three views on reference in literature: anti-reference, non-reference, and pro-reference. ${ }^{21}$ Anti-reference views include the pragmatic rejection of truth in favour of practical consequences and the structuralist and poststructuralist rejection of language providing access to reality. Non-reference views include conceptions of literature as self-referential or intertextual, i.e. referring only to other literary fictions. The former conception was particularly popular with New Criticism, the critical movement most closely associated with theories of form-content inseparability. Monroe Beardsley is perhaps the most well-known New Critic, maintaining that the literary work is an aesthetic object, self-contained, selfsufficient, and self-referential. ${ }^{22}$ The pro-reference view is the most popular in literary aesthetics and Friend distinguishes between fictional-object and make-believe theories within

\footnotetext{
${ }^{19}$ McGregor, "Poetic Thickness," 56.

${ }^{20}$ Malcolm Budd, Values of Art (London: Penguin, 1995), 4.

${ }^{21}$ Lamarque \& Olsen, Truth, Fiction, and Literature, 107.

${ }^{22}$ Monroe Beardsley, Aesthetics: Problems in the Philosophy of Criticism (New York: Harcourt, Brace \& World, 1958), 436-437.
} 
this category. ${ }^{23}$ She advances a version of the latter, in which there is make-believe reference to an existent object, in response to Frederick Kroon's defence of the former, in which there is genuine reference to a non-existent object. ${ }^{24}$ I shall return to the distinction between fictional-object and make-believe theories in $\S 4$, after elucidating a separate - but related distinction within pro-reference views of literature, between transparency and opacity. In both of the following sections, I shall focus on reference to real rather than fictional names in literary works. ${ }^{25}$

\section{Transparency \& Opacity}

Lamarque differentiates transparency and opacity as follows:

Only where the mode of narration is salient - in other words where the form in which a story is told matters in the appraisal of the narrative - will co-referential substitutions be blocked. Those narratives primarily concerned with imparting information - from homely conversational narratives to those of history or biography - will normally invite a transparent construal of their proper names and other referential devices. ${ }^{26}$

Narrative - or fictional - opacity is distinct from, but related to, W.V.O. Quine's referential opacity. Quine identifies several referentially opaque contexts, where the truth of a sentence depends upon something other than the referent such that truth is not preserved in co-

\footnotetext{
${ }^{23}$ Stacie Friend, "Real People in Unreal Contexts, or Is There a Spy Among Us?" in A. Everett \& T. Hofweber (eds.), Empty Names, Fiction and the Puzzles of Non-Existence (Stanford: CSLI Publications, 2000), 183-203: 183.

${ }^{24}$ Frederick Kroon, "Make-Believe and Fictional Reference," The Journal of Aesthetics and Art Criticism 52 (1994), 207-214.

${ }^{25}$ I do not have space to discuss reference to fictional names in this paper. My view - which is consistent with my argument for literary thickness - is that fictional names do refer, but to universals rather than particulars. ${ }^{26}$ Peter Lamarque, The Opacity of Narrative (London: Rowman \& Littlefield International, 2014), 146. The initial discussion of narrative opacity is by Lamarque and Olsen, who use the examples of "London" in the Sherlock Holmes stories, Tom Jones, and Bleak House (Truth, Fiction, and Literature, 80-82) and "Canterbury" in The Canterbury Tales (Truth, Fiction, and Literature, 126-128).
} 
referential substitutions. For example, although "Tegucigalpa" and "the capital of Honduras" have the same referent, co-referential substitution transforms true statement (1) into false statement (2):

(1) 'Philip believes that Tegucigalpa is in Nicaragua. ${ }^{, 7}$

(2) 'Philip believes that the capital of Honduras is in Nicaragua.' 28

Fictional opacity is not concerned with the preservation of truth, but with the preservation of the identity of the fictional work, specifically with the constraints it places upon one's imaginative engagement with that work. Lamarque is explicit that 'narrative opacity also shows how form helps determine content in prose narrative. ${ }^{29}$ Content is always shaped by form in a literary narrative such that the narrative is not transparent, i.e. one does not penetrate through the form straight to the content as one would in a philosophical or historical work.

Lamarque's conception of the contrasting degrees of opacity typical of literature and history can be demonstrated by comparing Hemingway's description of André Marty in For Whom the Bell Tolls with a passage from Antony Beevor's historical work, The Spanish Civil War. Beevor describes the arrival of volunteers for the International Brigades at Albacete late in 1936:

The recruits were lined up on the parade ground for an address by André Marty, the Brigades' controller who had earlier brought the French volunteers over the border during the fighting at Irún. Marty, a squat man, with a white moustache, drooping jowl and outsized beret, had made his name as a signals operator in the 1919 mutiny of the French Black Sea Fleet. The heroic legend woven around him in Party

\footnotetext{
${ }^{27}$ W.V.O. Quine, "Reference and Modality," in W.V.O Quine, From a Logical Point of View: 9 LogicoPhilosophical Essays (New York: Harper, 1963), 139-159, 141.

${ }^{28}$ Quine, "Reference and Modality," 141.

${ }^{29}$ Lamarque, Opacity of Narrative, 154.
} 
mythology made him one of the most powerful figures in the Comintern. Almost nobody dared challenge his authority. At that time he was starting to develop a conspiracy complex that rivalled Stalin's. Influenced by the show trials in Moscow, he became convinced that "Fascist-Trotskyist" spies were everywhere, and that it was his duty to exterminate them. Marty later admitted that he had ordered the shooting of about 500 Brigaders, nearly one-tenth of the total killed in the war. Many claim that Marty's figure is modest. ${ }^{30}$

The interest in the work is typically thin because form and content can be separated. The content - information about people, places, and events - can be separated from the form - the way in which Beevor presents them. The information in the text could be communicated in a different way without loss of identity. "Marty", "the parade ground", and "the show trials in Moscow" are not presented under an aspect, but transparently. "Marty" refers to Marty (i.e., "Marty" in its fully extensional use), not Marty-in-Beevor's-The-Spanish-Civil-War (i.e., Marty under the aspect Beevor's The Spanish Civil War licenses one to imagine). The people, places, and events can be described exhaustively without recourse to aspect. The Spanish Civil War is not intended for literary appreciation and my primary interest as a reader is with the content: I want to know if Marty really looked and acted as Beevor states, and because Beevor is a reputable historian I accept the invitation to believe his description.

Beevor's description of Marty contrasts with the character who makes a brief and sinister appearance in For Whom the Bell Tolls, even though it appears that Hemingway's portrayal of Marty is factually accurate:

He recognized his bushy eyebrows, his watery eyes, his chin and the double chin under it, and he knew him for one of France's great revolutionary figures

\footnotetext{
${ }^{30}$ Antony Beevor, The Spanish Civil War (London: Cassell \& Co., 2001), 184.
} 
who had led the mutiny of the French Navy in the Black Sea. Gomez knew this man's high political place in the International Brigades and he knew this man would know where Golz's headquarters were and be able to direct him there. He did not know what this man had become with time, disappointment, bitterness both domestic and political, and thwarted ambition and that to question him was one of the most dangerous things that any man could do. Knowing nothing of this he stepped forward into the path of this man, saluted with his clenched fist and said, "Comrade Marty, we are the bearers of a dispatch for General Golz. Can you direct us to his headquarters? It is urgent."

The tall, heavy old man looked at Gomez with his out-thrust head and considered him carefully with his watery eyes. Even here at the front in the light of a bare electric bulb, he having just come in from driving in an open car on a brisk night, his gray face had a look of decay. His face looked as though it were modelled from the waste material you find under the claws of a very old lion. ${ }^{31}$

For Whom the Bell Tolls does not authorise one to imagine "the man at the centre of l'affaire Marty-Tillon" when one reads "Marty". "Marty" in Beevor refers to Marty; "Marty" in Hemingway refers to Marty-in-For-Whom-the-Bell-Tolls, i.e. "Marty" presented under an aspect rather than in its full extension. The descriptions of real people, places, and events do not license one to invoke just any information about those people, places, and events in one's imaginative engagement with the novel because one's interest in the work is typically thick. ${ }^{32}$ The question of precisely what one is and is not licenced to imagine is particular to each literary work, but I have used an uncontroversial example in selecting a part of Marty's biography that occurred after the Spanish Civil War - the scandal which resulted in Marty

\footnotetext{
${ }^{31}$ Ernest Hemingway, For Whom the Bell Tolls (London: Grafton Books, 1976), 364-365.

${ }^{32}$ For a comprehensive discussion of referential, representational, and narrative opacity, see: Lamarque, The Opacity of Narrative, 3-14.
} 
being expelled from the Parti communiste français in 1952 - about which Hemingway could not have possibly known at the time of writing. ${ }^{33}$

It would be an error to state that For Whom the Bell Tolls does not refer to Marty, because the reader's experience of the novel is augmented by knowledge of the real Marty. The information from Beevor enhances the aspect under which Marty appears in For Whom the Bell Tolls. Hemingway offers a sketch of the relevant historical information, but the additional facts one finds in Beevor flesh out this representation and provide the informed reader with a richer and more rewarding experience. The words he stepped forward into the path of this man are that much more chilling with Beevor's facts to hand than they are without, relying only upon Hemingway's brief biographical description. For Whom the Bell Tolls is intended for literary appreciation and rewards the demand for literary thickness. I accept Hemingway's invitation to imagine certain things of Marty and my primary interest as a reader is with the way in which the content is combined with the form, a notion to which I shall return in $\S 5$.

\section{Fictional-Object Theories \& Make-Believe Theories}

Friend sets out the contrast between fictional-object and make-believe theories using the example of Shakespeare's Richard III: for the former, "Richard III" involves genuine reference to a non-existent object, Shakespeare's Richard of Gloucester; for the latter, "Richard III" involves make-believe reference to an existent object, i.e. we make-believe of the real King Richard that - for example - he murdered the princes (regardless of whether he did so in reality). In his defence of the fictional-object theory, Kroon notes that make-believe

\footnotetext{
${ }^{33}$ Friend offers a compelling account of prescriptions to imagine in terms of notion networks. See: Stacie Friend, "The great beetle debate: a study in imagining with names," Philosophical Studies 153 (2011), 183-211.
} 
theorists are committed to real names taking their usual referents, i.e. "Richard of Gloucester" in Shakespeare's Richard III refers to King Richard and "Jim Garrison" in Oliver Stone's JFK refers to Earl Carothers Garrison. ${ }^{34}$ Kroon identifies a paradox that make-believe theorists cannot explain. The real Garrison might, in the last year of his life, have watched $J F K$. He might also have both (1) despised himself and (2) admired the character in the film. ${ }^{35}$ As the make-believe theorist is committed to the view that "Jim Garrison" in JFK refers to Garrison, she is committed to the view that Garrison hates and admires himself simultaneously. The fictional-object theory involves no such paradox, because Garrison hates himself but admires the (non-existent) fictional Garrison. Kroon concludes that the fictional-object theory is therefore preferable to the make-believe theory. ${ }^{36}$

Friend's response is to show why the fictional-object theory fails, using an amusing story in which two real philosophers, Anthony Everett and John Perry, are revealed to be secret agents. She notes that 'the proper response to the fiction is to imagine, to make believe, that what is true in the fiction, really is true, that the events it narrates really have taken place'. ${ }^{37}$ Friend asks whether imagining Everett as a secret agent is imagining about the real Everett or imagining about a fictional Everett. She maintains the former, the consequence of which is that "Everett" can be substituted with any co-referential expression. ${ }^{38}$ Her evidence to support this claim is the response of the audience (which includes Everett): even though the audience know the story is fictional, they will still be imagining of and thinking about the philosopher in their midst as a spy. The claim is lent weight with a joke told about Perry, that

\footnotetext{
${ }^{34}$ Kroon, "Make-Believe and Fictional Reference," 207.

${ }^{35}$ Kroon, "Make-Believe and Fictional Reference," 210.

${ }^{36}$ In a subsequent paper, Kroon argues for a sophisticated make-believe theory based on the distinction, in fictions, between pretend-reference for real proper names and reference for fictional proper names. His solution relies on the significance of phrases such as as-he-is-in-the-movie and is not incompatible with that which I advance below. See: Frederick Kroon, “A Problem About Make-Believe,” Philosophical Studies 75 (1994), 201-229.

${ }^{37}$ Friend, "Real People in Unreal Contexts," 189.

${ }^{38}$ Friend, "Real People in Unreal Contexts," 191.
} 
he never tells jokes. ${ }^{39}$ The response of the audience, amusement, is based on the fact that the real Perry is well known for telling jokes. In other words, if one did not have the real Perry in mind - or if one does not know the real Perry - then the joke fails to be funny. Friend's argument is that the fictional-object theorist severs fiction from reality by stating that the fictions refer to the fictional characters, but engagement with the fictions discussed - Richard $I I I, J F K$, and her joke - is reliant upon audiences employing their knowledge of the real people represented. Friend's claim is thus that the fictional-object theorist cannot account for the joke being funny or the value of the way in which, for example, Hemingway weaves fact and fiction to produce a dramatic and realistic representation of the Spanish Civil War in For Whom the Bell Tolls. ${ }^{40}$ She concludes that the make-believe theory is therefore preferable to the fictional-object theory.

The debate between Friend and Kroon reveals a problem for each: Friend cannot account for Garrison both hating and admiring himself and Kroon cannot account for the audience's response to the story about Perry. I employed, perhaps controversially, utterance theories of both fiction and literature in $\S 1$ and thus made a commitment to distinguishing between fiction and non-fiction in terms of connecting fiction and literature with the imagination - or make-believe - and non-fiction with belief. My discussion of opacity and transparency made further use of this distinction, such that reading Hemingway involved imagining certain things about Marty while reading Beevor involved believing certain things about Marty. I now want to compare my distinction with that of Kroon and Friend. In my terminology, Kroon and Friend's respective positions can be set out as follows: fictional-object theories are

\footnotetext{
${ }^{39}$ Stacie Friend, "Real People in Unreal Contexts," 192.

${ }^{40}$ Friend subsequently rejects the standard philosophical distinction between fiction and non-fiction in terms of make-believe and belief in favour of her theory that fiction and non-fiction constitute different genres, where genres are understood as 'a way of classifying representations that guides appreciation' ("Fiction as a Genre," 181). The basis of her rejection is that make-believe is not restricted to fiction, i.e. both fictive and factive representations invite imaginings, a view which is supported by Matravers in Fiction and Narrative.
} 
opaque because the real names refer to fictional/non-existent rather than real objects and Garrison can thus hate himself while admiring his fictional counterpart; make-believe theories are transparent because real names invite imagination de re, i.e. employ "Richard of Gloucester" and "Jim Garrison" in their fully extensional use.

I claimed that the consequence of a thick interest in For Whom the Bell Tolls is that "Marty" in the novel refers to Marty-in-For-Whom-the-Bell-Tolls, i.e. the real Marty, but presented under the aspect that For Whom the Bell Tolls licences one to imagine. "Marty" thus refers to Marty, but - contra Friend - does not employ the name in its full extension. Understood in this way, literary thickness can solve both of the above problems. Friend's problem is solved because when Garrison watches Stone's film he is indeed watching himself, but Garrison-inJFK, i.e. himself under the aspect $J F K$ licences him to imagine. There is no inconsistency with Garrison's attitudes to himself and Garrison-in-JFK being different and the crime of libel concerns the exact opposite of Kroon's example, i.e. an individual disliking the aspect under which they have been presented in a particular representation. ${ }^{41}$ Kroon's problem is also solved, because "Perry" in Friend's story is Perry-in-Friend's-story and Friend's story is funny because it licences to imagine of the real Perry, well known for his jokes, that he is humourless. The incongruity between Perry and Perry-in-Friend's-story is precisely what makes Friend's story funny. ${ }^{42}$ The relation between real people, places, and events and the aspects under which they are presented in works of literature has been employed to great aesthetic effect by authors - a point to which I shall return in $\S 6$. The advantage of a thick interest in For Whom the Bell Tolls is thus that it retains the link between work and world (severed by Kroon) without the demand for transparency (made by Friend), i.e. facilitates

\footnotetext{
${ }^{41}$ Lamarque and Olsen offer an interesting discussion of the legal issues associated with Jilly Cooper's Rivals in the same context (Truth, Fiction, and Literature, 119-121).

${ }^{42}$ As mentioned above, my conception of Garrison-in-JFK is similar to Kroon's 'Garrison as he is in JFK' ("A Problem About Make-Believe," 224).
} 
make-believe with opacity and thus provides a convincing account of reference in literary fictions.

\section{Form, Content \& Function}

Fundamental to the author's intention - and therefore appreciation - is the idea that the appearance of a person, place, or event in a literary work serves a function within that work. It is not only the appearance of a person, place, or event which has one or more purposes, however, but also the way in which that person, place, or event is presented. The question of why thus applies to both the what and the how. The content of a work is formed just so for a reason; the specific combination of form and content is in each case deliberate. Selectivity is a feature of all representations of sequences of events, both narrative and non-narrative. In literary narratives, where the form is salient in addition to the content, this selectivity takes on an additional significance. Aristotle comments on the relationship between selectivity and function when he praises Homer for his unity of plot in the Odyssey:

the plot of a play, being the representation of an action, must present it as a unified whole; and its various incidents must be so arranged that if any one of them is differently placed or taken away the effect of wholeness will be seriously disrupted. ${ }^{43}$ If Homer could not present all of Odysseus' story, why did he select the parts of that story which appear in the Odyssey? Aristotle's answer is that he selected the parts that are essential to the plot or structure of the work, those which serve a particular function (or more likely functions) within the work as a unified whole.

\footnotetext{
${ }^{43}$ Aristotle, Poetics, trans. P. Murray \& T.S. Dorsch in P. Murray (ed.), Classical Literary Criticism (London: Penguin, 2004), 57-97: VIII, 1451a33-36.
} 
Lamarque states that the perspectival nature of literary narratives creates a "kind of "gestalt" of impressions and attitudes'. ${ }^{44}$ The narrative presents its content from a point of view and its particular combination of form and content will contribute to the gestalt that constitutes the work. Lamarque calls this the principle of functionality: 'broadly the idea that what is there (in the poem) is there for a purpose, things are not just accidentally as they are. ${ }^{45}$ The principle applies to both literary narratives and poems, but is more prominent in the latter: Reading poetry demands a sharper attention to detail than is characteristic of other kinds of reading, not surprisingly as the form of expression - the actual choice of words - is assigned unusual salience; that follows from the Principle of Functionality. ${ }^{46}$

While I am in agreement with Lamarque, I shall nonetheless make a slight amendment to the principle to draw attention to the significance of the relationship between literary form and literary content in both poetry and literary narratives:

PRINCIPLE OF FUNCTIONALITY: the idea that what is in the work is there for a purpose, i.e. things are not just accidentally as they are. The principle holds for all works of literature. Every sentence, arguably every word, is assumed to have a function in the work as a unified whole, within the interplay of themes and the developing picture of people, places, and events that comprise the work's content.

To demand literary thickness of a work is to attend to the operation of this principle in the text, to the combination of the what and the how of the work in terms of the why. In appreciating For Whom the Bell Tolls, therefore, one understands that Hemingway made a decision to include Marty as a character in his novel. He also decided that Marty would be presented in a particular way. The complexity of these choices is revealed in what is perhaps

\footnotetext{
${ }^{44}$ Lamarque, Opacity of Narrative, 160.

${ }^{45}$ Lamarque, "Poetic Meaning," 412.

${ }^{46}$ Lamarque, "Poetic Meaning," 412.
} 
the simplest part of this process, Hemingway's decision to offer a brief physical description of Marty. Given a desire for verisimilitude, the options seem fairly limited, and yet contrast Hemingway's description with Beevor's. Hemingway mentions Marty's eyebrows, eyes, and chin while Beevor mentions his physique, moustache, cheeks, and headgear. Interestingly, the descriptions are both entirely different and completely compatible. This array of choices would have increased exponentially when Hemingway decided which parts of Marty's biography and which aspects of his personality to include in the narrative. All these decisions about the what (or the who in this case) and the how are guided by the why. Hemingway's presentation of Marty under a particular aspect at a particular point in the narrative is designed to achieve a particular purpose - or purposes, in this case: at the level of the novel's plot, Marty frustrates the delivery of Robert Jordan's message, which is aimed at preventing the Republicans from launching an offensive for which the Nationalists are prepared; at the dramatic level, Marty’s appearance and intervention heightens the tension in the novel, the suspense as to whether the doomed offensive will or will not take place; at the thematic level, Marty heightens the sense of danger and distrust which permeates the entire novel, of people turning against their own in a civil conflict and betrayal by allies being as likely a cause of harm as enemy action. There are thus at least three answers to the why, and to appreciate literature is to be concerned with the relationships between not only form and content, but form, content, and function. Both the author's intention and the reader's response - where that response is appreciation - are guided by the principle of functionality.

It is difficult to deny the role of this principle without threatening the very concept of literature. In fact, the principle of functionality appears to hold not only for literature, but all art forms and artworks, and seems to have a necessary rather than contingent relation to art. The reason for this is the link to intentionality, as identified by Roger Scruton: 
Art provides a medium transparent to human intention, a medium for which the question, Why? can be asked of every observable feature, even if it may sometimes prove impossible to answer. ${ }^{47}$

Even in non-essentialist theories of art, there is an assumption that the work is an intentional creation. In the case of readymades like Duchamp's Fountain, the urinal was intentionally in Dickie's institutional terminology - presented to the artworld public, and the same applies to readymades appropriated from nature. Intentionality explains why the drawings of chimpanzees are not art and why a painted canvas that was indistinguishable from Pollock's Autumn Rhythm would not be considered a work of art if it was the result of canvas and paint falling from a truck. Art is bound up with the intention of an artist (or appropriator of readymades) and intentionality is bound up with the idea that every element of a work serves a function. ${ }^{48}$

The principle of functionality is crucial to both authorial intention and literary appreciation and the demand for literary thickness constitutes the match between the intended and recognised functions of the elements in the work, i.e. not just the what and the how, but why the content is formed in a particular way in the work. Given the importance of function to the relationship between form and content, literary thickness can be revised as follows:

LITERARY THICKNESS II: an interest in a literary work that involves attending to the combination of form and content in terms of function, i.e. the forming of content and the function of that formed content. Literary thickness is a demand which is satisfied by a work and is characteristic of literature such that if a work is a work of literature, it will reward the demand for literary thickness

\footnotetext{
${ }^{47}$ Roger Scruton, "Photography and Representation," Critical Inquiry 7 (1981), 577-603: 593.

${ }^{48}$ Note that in appreciating a work one can assume that every element has a function without assuming that the artist had an explicit intention regarding that function.
} 
Thus understood, literary thickness constitutes the match between authorial intention and reader response characteristic of literary work. In $\S \S 3-4$, I showed that literary thickness provides a convincing account of fictional reference by combining make-believe with opacity and I have therefore demonstrated that literary thickness is a valuable tool of literary appreciation. It may, however, be argued that I have stacked the odds in my favour by contrasting For Whom the Bell Tolls with The Spanish Civil War in my discussion of the contrasting interests readers bring to literature and history respectively. In the final section, I shall discuss Peter Carey's True History of the Kelly Gang as the novel constitutes a more compelling potential counter-example to my claim about the value of literary thickness.

\section{True History of the Kelly Gang}

Notwithstanding the local subject-matter, True History of the Kelly Gang is an international bestseller and also won Carey his second Booker Prize. The popular and critical success appears to be - at least partly - attributable to the peculiar relation between history and literature charted by the work. Carey himself noted that early responses to the work were 'as much as history as literature. But there have been some more sophisticated readings of it' ${ }^{49}$ The mismatch between authorial intention and reader response is hardly surprising, as Paul Eggert explains:

Unsophisticated readers are liable to believe that Carey's novel is a real autobiography, printed from a manuscript actually written by Ned Kelly. The first edition bears many factitious markers of historical authenticity: imitation quarterbound leather with the spine untitled as if it were an individually bound manuscript; sections individually guillotined rather than as a whole quire, creating something like

\footnotetext{
${ }^{49}$ Peter Carey cited in Nicholas Wroe, "Fiction's Great Outlaw," The Guardian, January 6, 2001, accessed February 20, 2014, <http://www.guardian.co.uk/books/2001/jan/06/fiction.petercarey>.
} 
a rough, deckled-edge finish; and speckled endpapers and textured paper-stock gesturing at the handmade. The novel itself is divided, not into chapters, but what purports to be a series of numbered manuscript parcels. ${ }^{50}$

The most informed reason for confusing literature with autobiography is not Carey's how, but his what. Aside from presenting numerous historical events, and weaving history into literature, Carey has selected in Kelly precisely the man who might have written the autobiography the reader appears to hold. Despite his lack of education - or perhaps because of it - Kelly was very much aware of the power of the press, and visited the office of the Ovens and Murray Advertiser to complain about his portrayal in the newspaper prior to being outlawed. He dictated the Cameron Letter, a seventeen page, three and a half thousand word letter to Joe Byrne (the most literate member of his gang) vindicating his actions before the Euroa bank robbery in December 1878. This was sent to Donald Cameron, a member of the Australian Legislative Assembly who had publicly criticised the police handling of the hunt for Kelly. Prior to the raid on Jerilderie in February 1879, Kelly dictated a fifty-six page, seven and a half thousand word letter to Byrne, and attempted to have the Jerilderie Letter printed and published at gunpoint. Neither of the letters reached the public due to concerns that they might result in popular support for Kelly's cause - and an insurrection may indeed have been his intention. Finally, Kelly dictated a letter to the Governor of Victoria six days before his execution, expressing his regret that he had been unable to make a fuller statement of his life and cause. ${ }^{51}$ Carey has seized the opportunity missed by Kelly, and produced a manuscript written under the premise of Kelly justifying his life to the daughter he has never met.

\footnotetext{
${ }^{50}$ Paul Eggert, “The Bushranger's Voice: Peter Carey's 'True History of the Kelly Gang' (2000) and Ned Kelly’s 'Jerilderie Letter' (1879),” College Literature 34 (2007), 120-139: 123.

${ }^{51}$ Eggert, “The Bushranger's Voice," 126-130.
} 
The daughter and her mother, Mary Hearn, are both fictional, but the history that emerges is an imaginative reconstruction of the life of a compassionate man doomed by social, economic - and possibly biological - influences to lead a life of violence, a course which he appears to have made every attempt to avoid. I lack space to offer a précis of the narrative, or a detailed account of Kelly as a character in True History of the Kelly Gang, but the portrayal of his personality is essential to understanding the work - qua autobiography or qua literature - and the following extract is representative:

I'm sure you know that I have spilled human blood when there were no other choice at that time I were no more guilty than a soldier in a war. But if there was a law against the murder of a beast I would plead guilty and you would be correct to put the black cap on your head for I killed my little heifer badly and am sorry for it still. By the time she fell her neck was a sea of laceration I will never forget the terror in her eyes. $^{52}$

Kelly's sensitivity to suffering and sense of responsibility are both conspicuous, extending even to an animal he is required to slaughter for food, and stand in stark contrast to his persona as a homicidal maniac following the murders at Stringybark Creek in October 1878. The treatment of his life in the narrative is stated succinctly and accurately by Mary in her comment on Kelly's Cameron Letter: 'she said there were not a soul alive who could read these words and blame me as the papers did. ${ }^{53}$

Bringing a thin interest to True History of the Kelly Gang is an easy error to make, but it remains an error because qua autobiography, the work is unsatisfying. In fact, it stalls at the first hurdle: the premise of the work, the thread which links the parcels together, is Kelly's relationship with Mary and his desire to communicate with their daughter - but both Mary

\footnotetext{
${ }^{52}$ Peter Carey, True History of the Kelly Gang (London: Faber \& Faber, 2001), 22.

${ }^{53}$ Carey, True History, 264.
} 
and the daughter are Carey's inventions. The novel refers to the real Kelly and appears to be transparent, but even if the narrative in the first seven parcels is entirely accurate, the appearance of Mary in the eighth marks an unambiguous parting with history. Yet Kelly's meeting with Mary, their conception of a child, and the addressing of the parcels as a letter to that child are obviously significant to both the understanding and the appreciation of the novel. I imagine that those unsophisticated readers who took a thin interest in the work and were inspired to research Kelly further would have been disappointed to discover that it contained such serious flaws qua history.

I mentioned that Carey binds fact and fiction together in his work, and the method is employed to the extent that he actually appropriates sentences from the Jerilderie Letter. ${ }^{54}$ The following two passages describe the same incident; the first is written by Kelly, the second by Carey:

(1) Mrs McCormack, "turned on me...I did not say much to the woman as my Mother was present but that same day me and my uncle was cutting calves Gould wrapped up a note and a pair of the calves testicles and gave them to me to give them to Mrs Mc Cormack....consequently Mc Cormack said he would summons me...He said I was a liar \& he could welt me or any of my breed I was about 14 years of age but accepted the challenge And dismounting when Mrs Mc Cormack struck my horse in the flank with a bullock's shin it jumped forward and my fist came in collision with Mc Cormack's nose And

\footnotetext{
${ }^{54}$ Eggert, "The Bushranger's Voice," 131.
} 
caused him to loose $[$ sic $]$ his equilibrium and fall postrate. ${ }^{55}$ (McDermott $2001,3-6) " 56$

(2) Then Mrs McCormick came rushing down the steps wielding a bullock's shinbone she must of picked up on the way. Mr McCormick followed behind her shouting out I were despised everyone in the district he said I were a coward and were hiding behind my mother's skirts. At this insult I dismounted. Mrs McCormick then struck my horse on the flank with her impertinent weapon and the horse jumped forward and as I were holding the rein it caused my fist to come into collision with McCormick's nose and he lost his equilibrium and fell prostrate. Tying up my horse to finish the battle I seen Cons Hall descend from the pub like a glistening old spider gliding down from the centre of its web. ${ }^{57}$

The first point to note is that although Carey writes in a vernacular similar to that which Kelly used, he does not replicate Kelly's diction exactly. The narrator of the parcels in True History of the Kelly Gang writes in a manner which is close enough to Kelly's actual style to maintain verisimilitude while making effective use of tropes and an understated expression of emotion. The idiosyncratic morphology and poor syntax are initially quite jarring: singlesentence paragraphs are composed of staccato phrases and clauses and there are no quotation marks to indicate direct speech. The mode of presentation engenders the experience of all thirteen parcels as something of an extended interior monologue, in spite of the numerous conversations that occur. Once one is attuned to the unruly grammar, however, the loss of clarity becomes a small price to pay for the lyrical quality of the prose, which at times

\footnotetext{
${ }^{55}$ There is no "sic" after "postrate", but the error is Kelly's rather than Eggert's. Eggert quotes from the first printed transcription of the Jerilderie Letter, which appears in Alex McDermott's The Jerilderie Letter (Melbourne: The Text Publishing Company, 2001).

56 Kelly cited in Eggert, "The Bushranger's Voice," 127.

${ }^{57}$ Carey, True History, 159.
} 
resembles the finest stream of consciousness writing and creates the desire for recital rather than reading. ${ }^{58}$ As a literary device, the narration of the novel is an essential part of the invitation to regard Kelly with sympathy as well as the force behind the forward-motion of the plot.

The second point to note is the implausibility of this incident in both accounts. Despite Kelly's claim about his age, he was probably sixteen when the clash with McCormick occurred - already physically capable, and no stranger to violence. ${ }^{59}$ McCormick's insult is a dire one as the opinion of many of Kelly's associates is that he has erotic feelings for his mother. ${ }^{60}$ There is no question that he intends to administer a beating to McCormick, and the description of Kelly's fist “accidentally” hitting McCormick's nose so hard that he knocks him down is unconvincing to the extent that - assuming this defence - the consequent custodial sentence comes as no surprise. Even if this particular incident did occur exactly as recorded in both of the above accounts, Carey casts doubt as to the reliability of Kelly's narration throughout the novel: his first shooting involves an unlikely suicidal charge by Bill Frost which leaves Kelly no choice but to shoot him; ${ }^{61}$ Mary is so certain of Kelly’s homicidal temper that she drugs him to prevent him murdering the father of her son; ${ }^{62}$ at Stringybark Creek, a reluctant and regretful Kelly single-handedly kills three policemen

\footnotetext{
${ }^{58}$ I do not have space to reproduce more of Carey's prose, but paradigmatic examples are: the description of Harry Power at Kelly's first robbery (True History, 70), Kelly's first sight of Mary (True History, 201), and the description of Kelly's mother after she has tried to shoot her partner, who has fathered Mary's child (True History, 219).

${ }^{59}$ In fairness, Kelly's precise date of birth is unknown, so the error may be due to his ignorance - or poor recall of event which had occurred just over eight years beforehand - rather than deliberate misrepresentation.

${ }^{60}$ See, for example: True History, 187, 193, 287 \& 308. Carey's Kelly does not have a physical relationship with his mother, but he certainly has an unnaturally strong attachment to a woman who demonstrates very little concern for him and betrays him several times. Ultimately Kelly chooses his mother over Mary, refusing to escape to America with her and their child.

${ }^{61}$ Carey, True History, 118.

${ }^{62}$ Carey, True History, 215.
} 
while his three compatriots kill none. ${ }^{63}$ When Kelly is outlawed the conflict escalates, and Carey establishes a subtle distance between reader and narrator such that one realises that one is no longer privy to Kelly's innermost thoughts, which in turn calls into question whether one ever was. His letter threatening to kill any resident of Victoria who assists the police in any way is shocking in both its violence and its hubris. Kelly concludes:

\section{DO NOT WISH TO GIVE THE ORDER FULL FORCE WITHOUT GIVING}

TIMELY WARNING BUT I AM A WIDOW'S SON OUTLAWED AND MUST BE

\section{OBEYED. ${ }^{64}$}

This is no longer the voice of the courageous but doomed victim of circumstances with whom one thinks one is familiar. The whole insurrection, which is such an important part of Kelly's life, is described in very little detail, except for the motive, which is to force the authorities to release his mother from prison. Again, there is a darkness and an arrogance that has not previously been disclosed - which is, of course, precisely what one would expect in a man who is attempting to justify his actions to a daughter whom he is likely never to meet.

True History of the Kelly Gang is thus not a straightforward sympathetic account, a history told from Kelly's point of view. Carey's work is instead Kelly's story: it is history in a literal sense; his story, told by him. The first clue to the complexity of the novel is in the title, the missing definite article before "true". This could reflect a grammatical error on the part of the uneducated narrator, but has a deeper significance in drawing attention to the first two words of the title. On a popular understanding, "true history" is redundant because if a history is not factual, then it is fictional and fails to qualify as history. On the other hand,

\footnotetext{
${ }^{63}$ Carey, True History, 237-244. The description of this incident is much more plausible than the McCormick and Frost confrontations, but following on from them as it does nonetheless contributes to the feeling that Kelly might not be telling the whole truth in his "true history".

${ }^{64}$ Carey, True History, 329. This sentence is actually appropriated from the Jerilderie Letter. See: Eggert, "The Bushranger's Voice," 128-129.
} 
Eggert $^{65}$ quotes Carey's claim to have deliberately selected the title for the purpose of signalling that the work is not a history - the idea being that contemporary professional historians are sceptical about the transparency of history. Whichever understanding one has of "true history", that it protests too much or that it is oxymoronic, the title serves to direct attention to the history-in-the-novel and the function the history-in-the-novel serves.

The form selected by Carey - the parcels, with their detailed notes, sandwiched between historical writing and the curious description of Kelly's death - interrupts the flow of Kelly's vernacular and disrupts the imaginative engagement with the novel, drawing attention in an explicit and overt manner to the purported historical character of the work. This effect is exacerbated at further points in the narrative: Kelly slips into the third person when he describes his apprenticeship to Harry Power ${ }^{66}$ and the related discovery of his mother's betrayal; ${ }^{67}$ he also describes events where he acknowledges his absence. ${ }^{68}$ Most telling, however, are the reproduction of newspaper articles with annotations, first by Mary, ${ }^{69}$ and then Kelly himself. ${ }^{70}$ One reads the newspaper articles with notes about their inaccuracy and is at the same time aware that the novel itself simultaneously represents and misrepresents historical events. The introduction to the eighth parcel casts a further doubt as to narrative veracity: 'Pages describing the shooting of Constable Fitzpatrick are much revised by a second hand reliably presumed to be that of Joe Byrne. ${ }^{71}$ Finally, there is Kelly's own commentary on the relation between history and truth, which includes passages such as the following:

\footnotetext{
${ }^{65}$ Eggert, "The Bushranger's Voice," 123.

${ }^{66}$ Carey, True History, 62-67.

${ }^{67}$ Carey, True History, 90.

${ }^{68}$ Carey, True History, 265-269.

${ }^{69}$ Carey, True History, 291-296.

${ }^{70}$ Carey, True History, 309-312.

${ }^{71}$ Carey, True History, 183.
} 
In the hut at Faithful's Creek I seen proof that if a man could tell his true history to Australians he might be believed it is the clearest sight I ever seen and soon Joe seen it too. ${ }^{72}$

I am not suggesting that True History of the Kelly Gang is not a sympathetic account of Kelly's life. It is, and despite the suggestions that he is not above omission or deception, there is no doubt that one comes to understand the situation in which Kelly and other poor immigrants - many of whom were either deported from the United Kingdom or the descendants of deportees - found themselves. For many Irish immigrants, like the Kellys, the one-sided conflict between landlords and peasants at home was simply relocated and reproduced in the colonial conflict between squatters and selectors. Carey's novel achieves something more than showing Kelly's side of the story, however: it presents his story, suggests that while a great deal of that story is probably true, some of it is probably not, and leaves the reader to pass his or her own judgement. To read the work qua literature is to accept Carey's explicit invitation to attend to the history-in-the-novel, and the function the combination of formal devices and historical content serves within this telling of Kelly's story as his story. This is, of course, to make a demand for literary thickness, to be concerned with not only the historical people, places, and events in the novel, but also how they are portrayed, why they are portrayed in that way, and their significance beyond the immediate context of Victorian Australia.

I chose True History of the Kelly Gang as work that appears to reward a thin rather than thick interest from readers. The novel also shows precisely what is wrong with fictional-object theories of fictional reference. If Kelly-in-True-History-of-the-Kelly-Gang is a fictional

\footnotetext{
${ }^{72}$ Carey, True History, 299.
} 
object then Carey's novel ceases to refer to the real Kelly, and it becomes difficult to see how the careful relation between fact and fiction to which I have alluded above could be relevant to an appreciation of the novel. Interestingly, a similar criticism could be made of formalist literary theories, such as those advanced by the New Critics. Both the fictional-object and formalist theorists separate work and world to some extent, despite the fact that the former hold pro-reference and the latter non-reference views of literature. The severing of the work from the world proposed by Beardsley means that appreciation is focused on form alone rather than form, content, and function, but if the novel did not refer to the real Kelly then the formal features employed by Carey could have no more than a superficial significance. The novel refers to the real people it names, but the combination of form and content produces opacity, such that one does not imagine Kelly in his full extension, but under the aspect licenced by Carey. My conclusion is that despite appearances to the contrary the demand for literary thickness is rewarded by True History of the Kelly Gang. If one accepts the necessity of the principle of functionality in all literary works, as suggested in $\S 5$, then this conclusion can be extended beyond Carey's novel. As such, literary thickness is the appropriate demand to make of all works characterised by an authorial intention for literary appreciation. ${ }^{73}$

\footnotetext{
${ }^{73}$ I would like to thank Stacie Friend and Peter Lamarque for their invaluable assistance with this paper.
} 